\title{
Occurrence of Ceratium furcoides (Levander) Langhans 1925 bloom at the Billings Reservoir, São Paulo State, Brazil
}

\author{
Matsumura-Tundisi, T. *, Tundisi, JG., Luzia, AP. and Degani, RM. \\ Instituto Internacional de Ecologia - IIE, \\ Rua Bento Carlos, 750, Centro, CEP 13560-660, São Carlos, SP, Brazil \\ *e-mail: takako@iie.com.br \\ Received January 08, 2010 - Accepted June 05, 2010 - Distributed October 31, 2010
}

(With 2 figures)

\begin{abstract}
An unusual bloom of Ceratium furcoides is reported for a station of the Taquacetuba compartment of the Billings Reservoir. The appearance of this bloom is attributed to the mixing and turbulence of the water column that removed Ceratium cysts from the surface of the sediment and promoted conditions for the growth of this species in the region of mixing. Cold fronts approaching the Billings Reservoir are probably the cause of the mixing and bloom. Also turbulence induced by wind increased phosphorus concentration in the water column. Ceratium furcoides was the dominant species at station 1 where the nutrient concentrations of nitrogen and phosphorus were high. Ceratium spp. blooms may be a problem for water treatment and massive mortality can affect the dissolved oxygen of the water producing fish kill.
\end{abstract}

Keywords: Ceratium furcoides, blooms, turbulence, cysts, cold fronts.

\section{Ocorrência de floração de Ceratium furcoides ( Levander) Langhans 1925, na represa Billings, Estado de São Paulo, Brasil}

\section{Resumo}

Neste trabalho, apresenta-se e discute-se a formação de florescimento de Ceratium furcoides no compartimento Taquacetuba da Represa Billings. Este florescimento é provavelmente resultado de intensa mistura vertical de coluna de água na região de transição entre este compartimento e o corpo central da represa. Esta mistura vertical é resultado do efeito de frentes frias sobre o sistema, promovendo interfaces que favorecem o aumento acentuado de fósforo na região do florescimento e o rápido crescimento de Ceratium furcoides. A turbulência gerada pode ter removido cistos da superfície do sedimento, promovendo o rápido crescimento desta espécie. O florescimento de espécies de Ceratium spp. pode ser problemático para o tratamento de água, pois pode causar depleção de oxigênio dissolvido após a decomposição, comprometendo a qualidade da água e aumentando os custos do tratamento.

Palavras-chave: Ceratium furcoides, floração, turbulência, cistos, mistura vertical.

\section{Introduction}

The occurrence of phytoplankton blooms in many eutrophic reservoirs of the world has been observed, as with genera of the Cyanophyta group, such as Microcystis, Anabaena, Cylindrospermopsis in some reservoirs. Another phytoplankton group, Dinophyta and the genus Ceratium bloom, has been registered. Ceratium's genera is normally found in waters rich in nutrients, especially phosphate and nitrate and usually in association with Cyanophyceae (Lund et al., 1965). Blooms of Ceratium hirundinella has been recorded in several standing freshwater bodies of the world, such as in Hartbeespoort Dam in South Africa by van Ginkel et al., 2001, in a large enclosure located in lake Biwa, Japan by Nakano et al., 1999. Nevertheless, Ceratium furcoides, a very similar species to Ceratium hirundinella, was recorded at first time in the hydroelectricity power plant at Furnas Reservoir, MG, Brazil, by Santos-Wisniewski et al., 2007.

The present work shows the occurrence of Ceratium furcoides on the Billlings's Reservoir (Braço Taquacetuba) for the first time. This urban reservoir, especially constructed for energy generation and supplying water, receives substantial quantities of domestics and industrial sewage, causing the deterioration of water quality and changing these systems to hipereutrophic systems. With this increase of nutrients, there are favourable conditions for the growth of some phytoplankton groups.

For a long time, the dominant phytoplankton community on the Billings Reservoir was Cianophyceae, according to Carvalho et al. (2007), and many articles on the phytoplankton of the Billings Reservoir described the transformation 
occurring in these water bodies including the development of Cyanophyta such as Microcystis, Planktothrix and Cylindrospermopsis. These authors related, over the last decade, frequent occurrences of Cyanophyta blooms with occurrences of the same genera previously cited.

\section{Material and Methods}

Limnological studies were carried out on August $19^{\text {th }}$ and $20^{\text {th }}$ of 2008 , in the Taquacetuba compartment of Billings Reservoir at the stations St1 (coordinates: $23^{\circ} 48^{\prime} 26.73$ " S and $46^{\circ} 37^{\prime} 30.41^{\prime \prime} \mathrm{W}$ ), St2 (coordinates: $23^{\circ} 49^{\prime} 32.90^{\prime \prime} \mathrm{S}$ and $46^{\circ} 37^{\prime} 57.69^{\prime \prime} \mathrm{W}$ ) and St3 (coordinates: $23^{\circ} 50^{\prime} 36.39^{\prime \prime} \mathrm{S}$ and $\left.46^{\circ} 39^{\prime} 20.89^{\prime \prime} \mathrm{W}\right)$.

Figure 1 shows the map of Billings Reservoir with the Taquacetuba compartment and the location of the three stations sampled.

At each station, local depth, temperature, $\mathrm{pH}$, dissolved oxygen and conductivity were measured using multiparametric sensors. Also, water samples were collected at the surface and other depths in order to measure Chlorophyll- $a$, dissolved inorganic phosphate, nitrate, total phosphorus and total nitrogen.

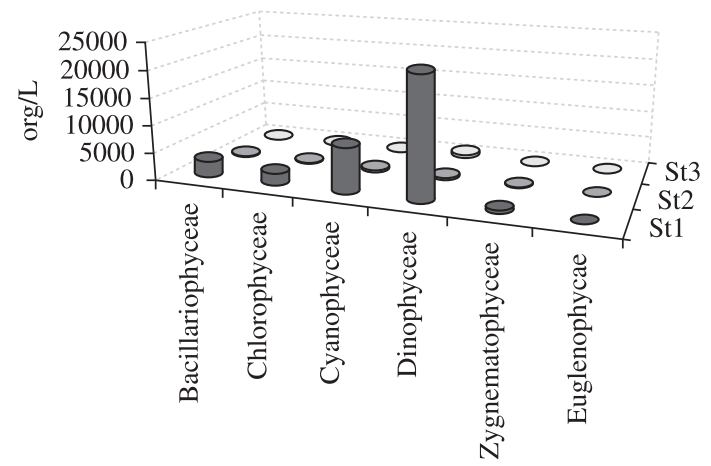

Figure 1. Density ( $\mathrm{n}^{\circ}$ org./L) of different classes of phytopplankton occurred in stations St1, St2 and St 3 of Taquacetuba compartiment of Billings Reservoir, SP, during August, 2008.
The phytoplankton samples were collected by vertical hauls using a plankton net with $20 \mu \mathrm{m}$ of aperture and the concentrate material was fixed with formalin solution $4 \%$. Qualitative and quantitative analyses of different groups were carried out by optic microscopy (Leica DMLB German), using a Sedgwick Rafter Counting Chamber with zoom of $200 \times$ and a subsample of $1.0 \mathrm{~mL}$. The bibliography used for phytoplankton identification was Bicudo and Menezes (2005), Bourrelly (1968), Komarek (1991), Mizuno (1964), Prescott (1966) and Streble and Krauter (1987).

\section{Results}

The Billings Reservoir has several compartments such as Taquacetuba and Riacho Grande where the limnological characteristics of the waters are quite different from the main compartment of the reservoir that receive a large quantity of sewage coming from the metropolitan region of São Paulo. Therefore, the phytoplankton community is different showing Cyanophyta blooms of Microcystis aeruginosa at all times. In the Riacho Grande compartment, studies performed by Matsumura-Tundisi et al., 2002, did not detect any occurrence of phytoplankton blooms.

At the Taquacetuba compartment, three stations were studied: St1 located near the main compartment of the reservoir, St 2 in the middle part, and $\mathrm{St} 3$, at the end of the compartment near the entrance of the tributaries.

Table 1 shows the main physical and chemical variables measured at St1, St2 and St 3 of Taquacetuba compartment of the Billings Reservoir.

As can be seen in Table 1, St1 presents higher concentrations of dissolved inorganic phosphate, nitrate and total phosphorus than St2 and St3. Dissolved oxygen and $\mathrm{pH}$ at the surface were very high, probably due to photosynthesis that can be seen by the high chlorophyll concentration presented at this station.

\subsection{Phytotplankton communities and the Ceratium furcoides bloom}

The phytoplankton bloom observed at station 1 (Figure 1) was due to the Dinophyceae with the growth of the Ceratium furcoides population. This species is very similar

Table 1. Limnological data at stations St1, St2 and St3 of Taquacetuba compartment of Billings Reservoir (SP).

\begin{tabular}{|c|c|c|c|c|c|c|}
\hline Stations & \multicolumn{2}{|c|}{ St1 } & \multicolumn{2}{|c|}{ St2 } & \multicolumn{2}{|c|}{ St3 } \\
\hline Local depth (m) & \multicolumn{2}{|c|}{10.0} & \multicolumn{2}{|c|}{5.5} & \multicolumn{2}{|c|}{5.5} \\
\hline Variables & Max & Min & Max & Min & Max & Min. \\
\hline Temperature $\left({ }^{\circ} \mathrm{C}\right)$ & 21.75 & 19.01 & 21.73 & 18.6 & 21.63 & 19.0 \\
\hline $\mathrm{pH}$ & 9.26 & 8.44 & 8.15 & 7.96 & 7.29 & 6.90 \\
\hline Conductivity $(\mu \mathrm{S} / \mathrm{s})$ & 285 & 275 & 260 & 249 & 247 & 238 \\
\hline Dissolved oxygen (mg/L) & 11.86 & 7.87 & 7.84 & 2.60 & 8.02 & 6.84 \\
\hline Chlorophyll $(\mu \mathrm{g} / \mathrm{L})$ & 186.6 & 59.79 & 12.32 & 9.18 & 13.01 & 5.22 \\
\hline Dissolved inorg. phosphate ( $\mu \mathrm{g} / \mathrm{L})$ & 11.47 & 5.07 & 2.53 & 1.87 & 4.47 & 2.13 \\
\hline Nitrate $(\mathrm{mg} / \mathrm{L})$ & 2.81 & 1.93 & 2.55 & 1.47 & 1.87 & 1.14 \\
\hline Amonium (NH4) & 0.0 & 0.0 & 0.0 & 0.0 & 0.0 & 0.0 \\
\hline Total phosphorus ( $\mu \mathrm{g} / \mathrm{L})$ & 140.45 & 72.0 & 26.0 & 19.0 & 26.0 & 24.0 \\
\hline Total nitrogen $(\mathrm{mg} / \mathrm{L})$ & 3.99 & 1.27 & 4.58 & 0.14 & 0.91 & 0.09 \\
\hline
\end{tabular}


to Ceratium hirundinella; however, it has some differences pointed out by Santos-Wieniewski et al., 2007. Figure 2 shows the general aspects of Ceratium furcoides obtained by image capture in the microscope, for the dorsal side (a), ventral side (b) and the schematic representation of the disposition of the plates at the dorsal valve (c) and the ventral valve (d).

According to Santos-Wieniewski et al., 2007, the main difference between the two species is the apical plates tabulation. $C$. hirundinella have 4 apical plates reaching the apex while in $C$. furcoides, 3 apical plates reach the apex and the $4^{\text {th }}$ does not reach the apex.

Table 2 shows the phytoplankton composition and its density (n.org/L) measured at the three stations of the Taquacetuba compartment of Billings Reservoir.

Besides the occurrence of the Ceratium furcoides bloom, the St1 was characterised by the presence of Cyanophyceae, mainly the genus Oscillatoria and the presence of Phacus, Euglenophyceae characterising an environment rich in organic material.

\section{Discussion}

Reynolds (1997), when presenting theories and hypothesis related to the succession and development of phytoplankton populations in pelagic environments, emphasises the importance of the matrix of possibilities related to the distribution of downwelling irradiance and limiting nutrient concentration in relation to mixed depth represented by temperature distribution and algal growth supporting capacity. Therefore, the succession of phytoplankton in pelagic environments is dependent on the temporal organization of the vertical axis energy and nutrients. Disturbances in the pelagic populations represented by the appearance of large numbers of one species, as blooms, are attributed to sudden changes in vertical stability, depletion of nutrients and alterations in the underwater light climate. This is referred to by Reynolds (1997) as a "pulsed resource exploitation" resulting in a large population of a single species.

Episodes of the growth of massive populations of Ceratium hirundinella in Heart Lake, Ontario (Nicholls et al., 1980), Hartbeespoort Dam, South Africa (van Ginkel et al., 2001) have been reported. A fish kill in Heart Lake associated with a collapse of the massive population of Ceratium hirundinella, was reported by Nicholls et al. (1980).

Ceratium furcoides was reported in Furnas Reservoir (MG) as an invasive species by Santos-Wisniewski et al. (2007).

In Fetsui Reservoir, Taiwan, the abundance of Ceratium furcoides was positively correlated with phosphorus, total organic carbon, bacterial numbers and the biochemical oxygen demand in the water. According to Moya and Ramon (1984), cysts of Ceratium are found on the surface of the sediments. Thus the presence of these blooms can be attributed to the presence of resistance forms in the sediments of Billings Reservoir. These resistance forms were removed by the mixing effect.

Ceratium furcoides was dominant over other genera of phytoplankton at Station 1. In the Taquacetuba branch, very high phosphorus concentration occurred at this station. Station 1 is located in a region of mixing of waters from the main compartment of Billings Reservoir and the Taquacetuba branch.

As Demers and Legendre (1981) pointed out, mixing of two water masses can destabilise the water column favouring the replenishment of the surface layer in nutrients and removing the surface of the sediments thus promoting
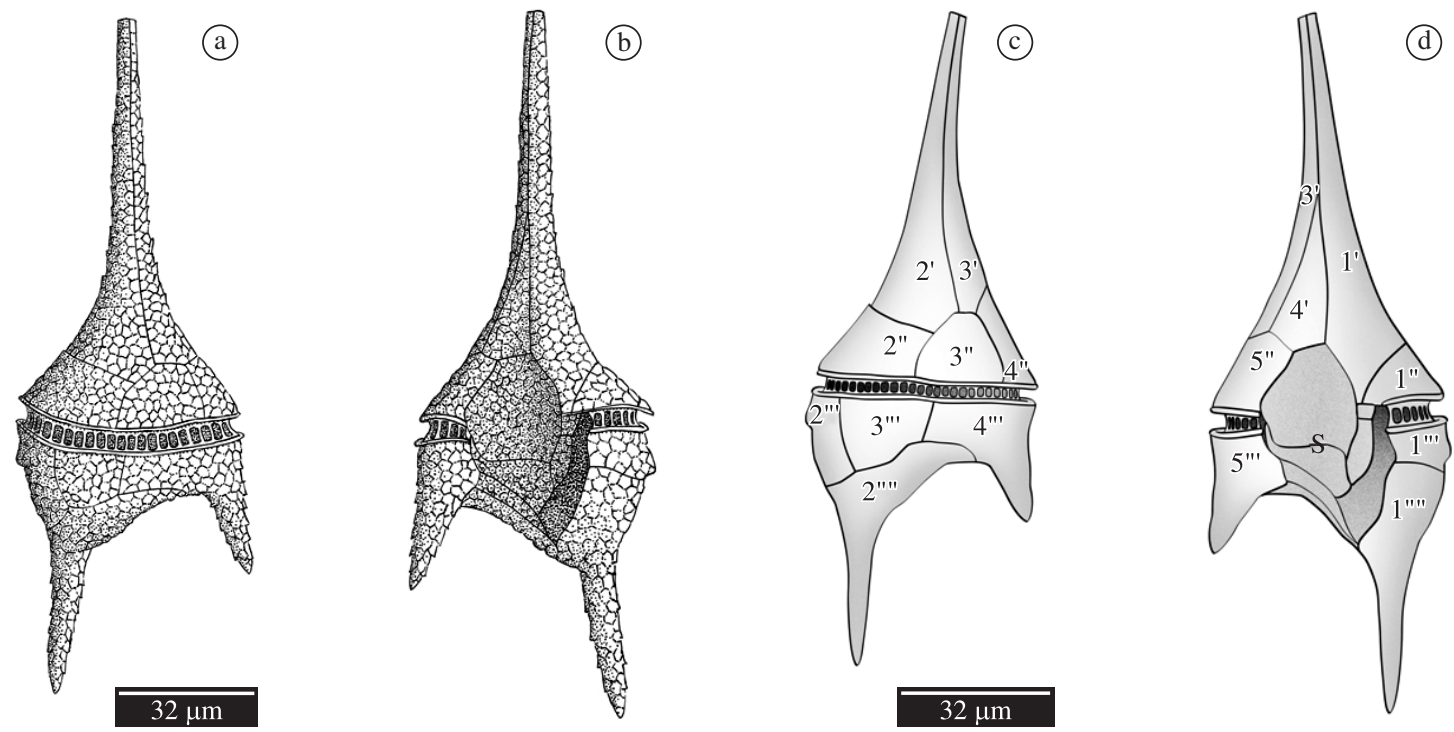

Figure 2. General aspects of Ceratium furcoides: (a) dorsal view; (b) ventral view; schematic representation of the disposition of the plates at the dorsal valve (c) and the ventral valve (d). 
Table 2. Phytoplankton composition and its density ( $n^{0}$ org./L) in the Taquacetuba compartment of Billings Reservoir in São Paulo State.

\begin{tabular}{|c|c|c|c|}
\hline Sampling stations & St1 & St2 & St3 \\
\hline Data & $19 / 08 / 2008$ & $19 / 08 / 2008$ & $19 / 08 / 2008$ \\
\hline \multicolumn{4}{|l|}{ BACILLARIOPHYCEAE } \\
\hline Fragillaria & 15570 & 0 & 0 \\
\hline Asterionella & 311394 & 11121 & 3244 \\
\hline Aulacoseira & 2692144 & 297493 & 9731 \\
\hline \multicolumn{4}{|l|}{ CLHOROPHYCEAE } \\
\hline Asterococcus & 77849 & 0 & 0 \\
\hline Botryococcus & 31139 & 5561 & 0 \\
\hline Chlorella & 373673 & 77849 & 12975 \\
\hline Chlorococcum & 186837 & 91750 & 74605 \\
\hline Coelastrum & 15570 & 0 & 0 \\
\hline Dictyosphaerium & 155697 & 11121 & 0 \\
\hline Desmodesmus & 15570 & 0 & 0 \\
\hline Kirchineriella & 358103 & 69508 & 6487 \\
\hline Micractinium & 591649 & 30583 & 3244 \\
\hline Oocystis & 15570 & 5561 & 3244 \\
\hline Pediastrum & 171267 & 38924 & 19462 \\
\hline Radiococcus & 15570 & 5561 & 0 \\
\hline Scenedesmus & 217976 & 13902 & 16218 \\
\hline Selenastrum & 15570 & 11121 & 0 \\
\hline \multicolumn{4}{|l|}{ CYANOPHYCEAE } \\
\hline Anabaena & 15570 & 5561 & 0 \\
\hline Chroococcus & 404812 & 100091 & 64874 \\
\hline Microcystis & 186837 & 13902 & 0 \\
\hline Oscillatoria & 7753715 & 467091 & 74605 \\
\hline \multicolumn{4}{|l|}{ DINOPHYCEAE } \\
\hline Ceratium & 21455060 & 544940 & 535209 \\
\hline Peridinium & 1027601 & 38924 & 19462 \\
\hline \multicolumn{4}{|l|}{ ZYGNEMATOPHYCEAE } \\
\hline Closterium & 15570 & 116773 & 3244 \\
\hline Closteriopsis & 77849 & 2780 & 0 \\
\hline Mougeotia & 529370 & 88970 & 38924 \\
\hline Staurastrum & 62279 & 5561 & 0 \\
\hline \multicolumn{4}{|l|}{ EUGLENOPHYCEAE } \\
\hline Hyalophacus & 0 & 2780 & 0 \\
\hline Phacus & 46709 & 0 & 0 \\
\hline
\end{tabular}

the development of phytoplankton blooms, in this case Ceratium furcoides.

Nutrient concentration in these mixed layers can be very high and phytoplankton appears to respond rapidly to these charges as pointed out by Legendre (1981).

Further evidence of the mixing effect on the appearance of the blooms of Ceratium furcoides is the effect of the cold fronts on the vertical mixing of the water column at station 1. Before the occurrence of the bloom, a cold front was approaching from the southern region to São Paulo State. Tundisi et al. (2010 in press) demonstrated that wind velocity is higher during the days immediately before the cold front promoting mixing in the water column. Turbulence is maintained during the passage of cold fronts.

Episodes of vertical mixing and changes in the structure of the water column associated with the passage of cold fronts were described by Tundisi et al. (2004), for the UHE Carlos Botelho (Lobo/Broa) reservoir. These episodes explain the changes in the succession of phytoplankton associated with the periods of stratification and mixing of the water column (Lund, 1965). 
Ceratium furcoides blooms can be harmful to fishes due to decomposition and oxygen depletion after the collapse of these massive populations. But also it can be a problem for water treatment. Since the Taquacetuba branch of the Billings Reservoir has its water used for public supply, a more accurate sampling program for detection and follow up of further occurrence of these blooms is required.

Acknowledgements - The authors acknowledge the support of Dersa (State of São Paulo Government) and Biota/ Fapesp.

\section{References}

BICUDO, CE. and MENEZES, M. (Eds)., 2005. Gêneros de Algas de águas Continentais do Brasil. São Carlos: RIMA. 508 p.

BOURRELLY, P., 1968. Les algues d'eau douce. Initiation à la systématique. Tome II: Les algues jaunes et brunes. Chrysophycées, Pheophycées, Xanthophycées et Diatomées. Paris: Boubée et Cie.

CARVALHO, LR., SANT'ANNA, CL., GEMELGO, MCP. and AZEVEDO, MT., 2007. Cyanobacterial occurrence and detection of microcystin by planar chromatography in surface water of Billings and Guarapiranga Reservoirs, SP, Brazil. Revista Brasileira de Botanica, vol. 30, no.1, p. 139-146.

DEMERS, S. and LEGENDRE, L., 1981. Mélange vertical et capacité photosynthétique du phytoplankton estuarien (estuaire du Saint-Laurent). Marine Biology, vol. 64, p. 243-250.

GINKEL, CE. van, HOHLS, BC. and VERMAAK, E., 2001. A Ceratium hirundinella (O.F. Müller) bloom in Hartbeespoort Dam. WaterSA, vol. 27, no. 2, p. 269-276.

KOMÁREK, J., 1991. A review of water-bloom forming Microcystis species, with regard to population from Japan. Algological Studies, vol. 64 , p. 115-127.

LEGENDRE, L., 1981. Hydrodynamic control of marine phytoplankton production: the paradox of stability. In NIHOUL, JC. (Ed). Ecohydrodynamics. Amsterdam: Elsevier. p. 191-207.

LUND, JWG., 1965. The ecology of the freshwater phytoplankton. Biological Reviews, vol. 40, p. 231-293.

MATSUMURA-TUNDISI, T., TUNDISI, JG. and ROCHA, O. 2002. Zooplankton diversity in eutrophic system and its relation to the occurrence of cyanophycean blooms. Verhandlungen. Internationale Vereinigung Limnologie. vol. 28, no. 2, p. 671-674.

MIZUNO, T., 1964. Illustration of freshwater plankton of Japan. Japan: Hoikusha. 351 p.

MOYA, G. and RAMON, G. 1984. Variacion espacio temporal de Ceratium hirundinella en los embalses de Cuber y Gorg Blan (Malhorca). Limnética, vol. 1, p. 285-290.

NAKANO, S., NAKAJIMA, T., HAYAKAWA, K., KUMAGAI, M. and JIAO, C., 1999. Blooms of the Dinoflagellate Ceratium hirundinella in large enclosures placed in Lake Biwa. Japanese Journal of Limnology, vol. 60, p. 495-505.

NICHOLLS, KM., KENNEDY, W. and HANNET, C., 1980. Fish kill in Heart Lake, Ontario, associated with the collapse of a massive population of Ceratium hirundinella. (Dinophyceae). Freshwater Biology, vol. 10, no. 6, p. 553-561.

PRESCOTT, GW., 1966. Algae of the Western Great Lake Area. Dubuque: W.M.C. Brown Company Publ. 577 p.

REYNOLDS, CS., 1997. Vegetation processes in the pelagic: a model for ecosystem theory. Germany: Ecology Institute, 371 p.

SANTOS WISNIESWKI, MJ., SILVA, LC, LEONE, IC., LANDARES-SILVA, R. and ROCHA, O., 2007. First record of the occurrence of Ceratium furcoides (Levander) Langhans 1925, an invasive species in the hydroelectricity power plant Furnas Reservoir, MG, Brazil. Brazilian Journal of Biology, vol. 67, no. 4, p. 791-793.

STREBLE, H. and KRAUTER, D., 1987. Atlas de los Microrganismos de Agua Dulce. La vida em uma gota de água. Barcelona: Ediciones Omega, S. A. 364 p.

TUNDISI, JG., MATSUMURA-TUNDISI, T., ARANTES Jr., JD., TUNDISI, JE., MANZINI, N F. and DUCROT, R., 2004. The responses of Carlos Botelho (Lobo-Broa) reservoir to the passage of cold fronts as reflected by physical, chemical and biological variables. Brazilian Journal of Biology, vol. 64, p. 177-186.

TUNDISI, JG., MATSUMURA-TUNDISI, T., LUZIA, AP., PASOERINI, MO., CHIBA, W. and SEBASTIAN, NY., in press. Cold fronts and reservoir limnology: an integrated approach towards the ecological dynamics of freshwater ecosystems. Brazilian Journal of Biology. 